Original Article

\title{
Synthesis, characterization and protection effect of black rice anthocyanins nano-composite against hepatotoxicity induced by methotrexate in rats
}

\author{
Síntese, caracterização e efeito protetor de nanocompósito de antocianinas de arroz \\ preto contra hepatotoxicidade induzida por metotrexato em ratos
}

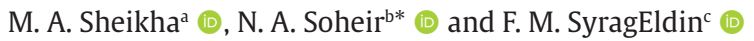 \\ Imam Abdulrahman Bin Faisal University, College of Science, Department of Chemistry, Dammam, Saudi Arabia

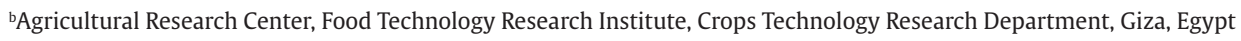 \\ 'Saudi Grains Organization - SAGO, Center Lab. of Research, Riyadh, KSA
}

\begin{abstract}
The present study aimed to investigate the beneficial of prepared black rice anthocyanins nano-composite (An$\mathrm{AgNp}_{\mathrm{s}}$ ) against hepatotoxicity induced by methotrexate (MTX) in rats. Anthocyanins nano-composite was prepared by silver as the metallic ion reduction and were characterized by IR and SEM. The rats in our experiment were divided into five groups. Serum lipid profile, serum transaminases (ALT and AST), ALP, LDH, TBA, GSH and SOD were examined. The results show that SEM of $A n-\mathrm{AgNp}_{\mathrm{s}}$ has average particle size from 70 to $130 \mathrm{~nm}$. In the group treated with MTX; TC, TG, LDL-c, ALT, AST, ALP, LDH and TBA levels were significantly ( $\leq 0.05)$ increased than $\mathrm{NC}$, while, HDL-c, SOD and GSH levels were significantly $(\mathrm{P} \leq 0.05)$ decreased. On the other hand, An-AgNp $\mathrm{s}_{\mathrm{s}}+\mathrm{MTX}$ treated groups were reversed the levels of all biomarkers similar to NC. In conclusion, the results show that An$\mathrm{AgNp}_{\mathrm{s}}$ has a protective effect on MTX-induced hepatotoxicity and oxidative stress.
\end{abstract}

Keywords: anthocyanins nano-composite, hepatotoxicity, methotrexate, black rice, infrared spectroscopy, scanning electron microscopy.

\begin{abstract}
Resumo
O presente estudo teve como objetivo investigar o benefício de nanocompósito de antocianinas de arroz preto preparado (An-AgNps) contra a hepatotoxicidade induzida por metotrexato (MTX) em ratos. O nanocompósito de antocianinas foi preparado a partir da prata por meio da redução do íon metálico e caracterizado por IR e SEM. Os ratos em nosso experimento foram divididos em cinco grupos, e foram examinados o perfil lipídico sérico, as transaminases séricas (ALT e AST), ALP, LDH, TBA, GSH e SOD. Os resultados mostram que SEM de An-AgNps tem tamanho médio de partícula de 70 a $130 \mathrm{~nm}$. No grupo tratado com MTX, os níveis de TC, TG, LDL-c, ALT, AST, ALP, LDH e TBA aumentaram significativamente $(P \leq 0,05)$ do que NC, enquanto os níveis de HDL-c, SOD e GSH diminuíram significativamente $(\mathrm{P} \leq 0,05)$. Por outro lado, nos grupos tratados com An-AgNps $+\mathrm{MTX}$, foram revertidos os níveis de todos os biomarcadores semelhantes ao NC. Em conclusão, os resultados mostram que o An-AgNps tem um efeito protetor contra a hepatotoxicidade induzida pelo MTX e o estresse oxidativo.
\end{abstract}

Palavras-chave: nanocompósito de antocianinas, hepatotoxicidade, metotrexato, arroz preto, espectroscopia de infravermelho, microscopia eletrônica de varredura.

\section{Introduction}

Methotrexate (MTX) (4-amino-N10-methyl folic acid) has been used in the various therapy types of diseases includingpsoriasis, cancers immunologic disorders, Crohn's disease, rheumatoid arthritis, for the multiple sclerosis treatment, sarcoidosis, dermatomyositisand stage of various cancerous (breast cancer, lung cancer, head and neck tumours, lymphoma, leukemia, osteosarcoma, etc.) (Ozogul et al., 2013; Vardi et al., 2010; Celik et al., 2013). Additionally, long-term administration or high doses of MTX has toxic side effect on tissue of liver (Kumari, 2016) and seems to relate to reactive oxygen species (ROS) generation (Şener et al., 2006a). Decreased the count of white blood cell, hepatotoxicity and ulcerative stomatitis are the most common adverse effects of MTX (Şener et al., 2006b).

Nanoparticles are engineered materials produced within the nanoscale range of 1-100 $\mathrm{nm}$ in one or more dimensions (Barnes et al., 2008). In all the metals the pure silver has the highest thermal conductivity, and electrical, and has

*e-mail: soheirkenawy@yahoo.com

Received: February 13, 2021 - Accepted: December 12, 2021 
low resistance of contact (Thomas and Sayre, 2005). In various fields many applications of silver nanoparticles (AgNPs) are widely used including bacteria, sensors, virus, catalysis high proportion of surface atoms, bio labeling, antimicrobial agents, filters, microelectronics (Tavares et al. 2012), because they have specific biological and physicochemical properties (Rai et al., 2009). AgNPs synthesis from the phytochemical by using fruit or plants extracts plays an important role in the field of nanomedicine and nanotechnology as it offers alternative therapeutic options which are free side effects, effective for a wide variety of diseases and safe (David et al., 2014).

Anthocyanins has polyphenols typical chemical structure and belong to flavonoids (Kong et al., 2003), and they have diverse healthy functions including antiproliferative activities, anti-inflammatory, antioxidant and anti-cancerous and their most attractive biological feature might owe to their capacity to affect the growth of vulnerable micro-organisms (Bowen-Forbes et al., 2010), therefore, they considered health-promoting substances. Based on the anthocyanin's antioxidant capacity, they are exhibit many bioactivities such as Alzheimer's disease, prevention and preservation of vision etc. (Miyake et al., 2012). Many studies reported that the extracts of anthocyanin from plants and natural food have hepatoprotective effect and believed to be beneficial to liver health, because they have strong antioxidant activity (Sankhari et al., 2012). The anthocyanins phenolic hydroxyl groups causing a reduced in anthocyanins biological activity because they are oxidized easily into quinones, as a result of that, the anthocyanins get unstable and need to combine with macromolecules to increase their stability (Amin et al., 2017). Therefore, our present study aimed to increase the stability of anthocyanins by synthesis anthocyanins silver nanoparticles, characterize the prepared nanoparticles and investigate its protective effects on liver hepatotoxicity induced by Methotrexate.

\section{Experimental Methods}

\subsection{Extraction of anthocyanin from black rice}

The black rice was requested from Agriculture Research Center, Gize, Egypt. The extract of anthocyanin from soft black rice was produced by adding $100 \mathrm{~g}$ from the black rice powder into $150 \mathrm{~mL}$ methanol and stirred for $24 \mathrm{~h}$. The final extracted was centrifuged to gain the black rice anthocyanin extract (Septiani et al., 2017).

\subsection{Preparation of anthocyanin silver nanoparticles}

Black rice anthocyanin with the metallic ion reduction were used to obtained anthocyanin silver nanoparticles. $\mathrm{NaOH}$ solution $(1 \mathrm{M})$ was used to brought black rice anthocyanin extract at value of $\mathrm{pH}=7.5$. 0.06M $\mathrm{AgNO}_{3}$ concentration was used to synthesis anthocyanin nanoparticles: added metallic ion solution $(6.6 \mathrm{~mL})$ and anthocyanin black rice extract $(16.6 \mathrm{~mL})$ to boiling distilled water $(200 \mathrm{~mL})$. Note the change in color immediately, indicated that the anthocyanin silver nanoparticles are obtained. After that, stopped the heating and continues the stirring till to cool the solution (Olenic and Chiorean, 2015).

\subsection{Biological methods}

Fifty male waster albino rats $(230 \pm 270 \mathrm{~g})$ were purchased from the Vaccination Centre, Helwan, Giza, Egypt. They were kept under the standard conditions of the animal house of Ophthalmology Research Institute, Giza, Egypt with a $12 \mathrm{~h}$ light/dark cycle at temperature $21 \pm 0.5^{\circ} \mathrm{C}$ and relative humidity $55 \pm 5$. During a 10 days period, they had nutrition diet contains (salt mixture $4 \%$, corn seed oil $10 \%$, vitamins mixture $1 \%$, corn starch $70 \%$, casein $10 \%$ and cellulose 5\%).The experimental animals were randomly divided into five groups of ten animals. G1; Normal Control (NC) group, G2; Positive Control (PC) group was treated with single dose of MTX (20 mg/kg.b.w) i.p injection, G3; treated group was treated with single dose of MTX (20 mg/kg.b.w) i.p injection + An-AgNPs (10 mg/kg.b.w), G4; treated group was treated with single dose of MTX (20 mg/kg.b.w) i.p injection + An-AgNPs (15 mg/kg.b.w), G5; treated group was treated with single dose of MTX (20 mg/kg.b.w) i.p injection + An-AgNPs (20 mg/kg.b.w). The treated animals were kept for 10 days. Then,food intake and body weight were measured at the beginning and during the experimental period. After the treated period, a blood samples were taken from the orbital plexus using a mean of heparinized capillary glass tubes to obtain the blood serum, each sample was centrifuged (1500 xg at $4^{\circ} \mathrm{C}$ for $\left.30 \mathrm{~min}\right)$.

\subsection{Biochemical assays in serum}

\subsubsection{TC, TG, HDL, LDL assays}

Triglycerides (TG) (Fossati and Prencipe, 1982), Total cholesterol (TC) (Allain et al., 1974), High density lipoprotein (HDL-C) (Lopez-Virella et al., 1977) and lowdensity lipoprotein (LDL-C) (Friedewald et al., 1972) were determined by kits obtained from bio diagnostic company, Dokki, Giza, Egypt.

\subsubsection{SALT, sAST, ALP and LDH assay}

Serum transaminases ALT and AST (Alanine transferase and Aspartate transferase) were measured calorimetrically according to the method described by Reitman and Frankel (1957). Serum alkaline phosphatase (ALP) and lactate dehydrogenase activities (LDH) were determined according to Bablok et al. (1988).

\subsubsection{TBA assay}

The method describes by Mihara and Uchiyama (1978) was used to determine the thiobarbituric acid (TBA). A mixture of $3 \mathrm{~mL}$ phosphoric acid (1\%, pH 2.0) and $1 \mathrm{~mL}$ of TBA $(0.6 \%)$ were added into $0.5 \mathrm{~mL}$ of the blood serum in airtight tubes and kept for $45 \mathrm{~min}$ in a boiling water bath. Then, cooled the samples in ice and add $5 \mathrm{~mL}$ butanol along with through the mixture mixing. Using $1000 \mathrm{xg}$ centrifugation to separate the butanol phase and transferred into glass cuvettes. Spectrophotometer (Bauch and Lomb, Spectronic-20) was used to measure the color 
of the TBA chromogen at 520 and $532 \mathrm{~nm}$. The value of TBA was observed by measuring the difference between absorbance value at 520 and at $532 \mathrm{~nm}$, which represents the concentration of malondialdehyde, and was taken as the measure of lipid peroxidation.

\subsubsection{SOD and GSH assay}

The measurement of serum Superoxide dismutase (SOD) enzymatic activity was followed as reported by Ohkuma et al. (1982). Glutathione (GSH) was tested according to the method described by Ellman (1959). GSH was interacted with 5,5'-dithiobis-2-nitrobenzoic acid. After that, the product absorbance spectra were measured at $410 \mathrm{~nm}$ (maximum absorbance). The $\mu \mathrm{mol} / \mathrm{g}$ tissue was used to express the final results.

\subsection{Statistical analysis}

The mean SEM was used to express the results and ANOVA (one-way analysis of variance) was used to measure the intergroup variation, which followed by Fischer's LSD test. Statistical significance was considered at $(\mathrm{P} \leq 0.05)$. Then, we used the Jandel Sigma Stat Statistical Software version 2.0 to analyze the statistical value.

\section{Results and Discussion}

Figure $1 \mathrm{a}$ and $1 \mathrm{~b}$ show the FTIR spectroscopic analysis of silver nitrate only (1A), silver nano-particles/ anthocyanins nanocomposite (2A) and anthocyanines only (3A). This figure shows a difference between the three spectrums as follow: 1) The characteristic bands of silver nitrate which appear at 2715.7, 2409, 1772.6 and
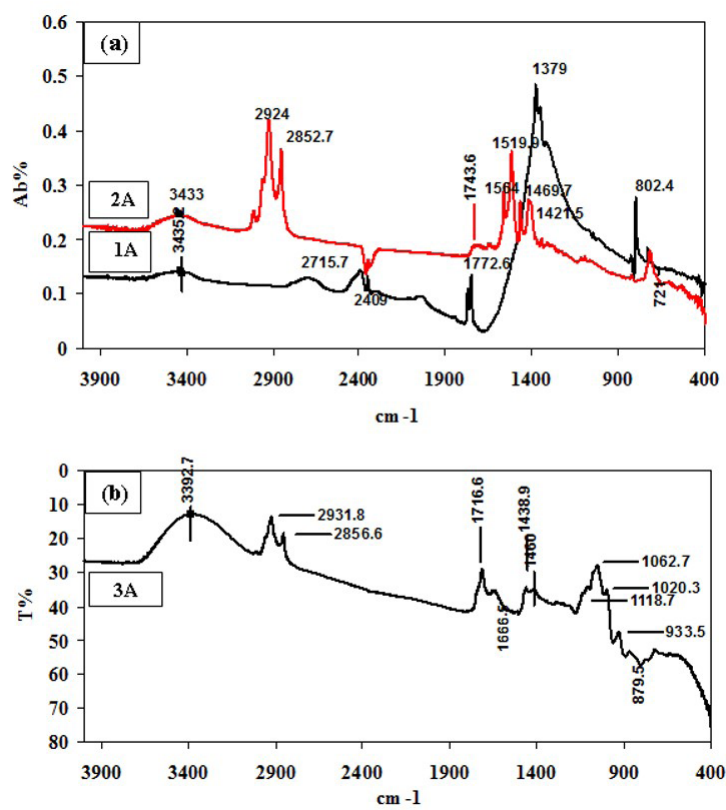

Figure 1. FTIR spectroscopic analysis of (a) silver nitrate (1A) and silver nano-particles/ anthocyanins nano-composite (2A), (b) anthocyanines only (3A).
$1379 \mathrm{~cm}^{-1}$ (in $1 \mathrm{~A}$ ) are disappear in $2 \mathrm{~A}$ and that appeared at $721 \mathrm{~cm}^{-1}$ shifted to $802.4 \mathrm{~cm}^{-1}$ in 2A mostly indicates a good interaction between anthocyanines molecules and the silver nano-particles. 2) Stretching vibration of $\mathrm{OH}$ groups in anthocynines give broad band at $3392.7 \mathrm{~cm}^{-1}$ (in $3 \mathrm{~A}$ ) shifted to $3433 \mathrm{~cm}^{-1}$ (in $2 \mathrm{~A}$ ) with about $40.3 \mathrm{~cm}^{-1}$. This indicates the breaking of some $\mathrm{H}$-linkages of anthocyanines due to its interaction with the silver surface. 3) Three characteristic bands of anthocyanines appeared around $2931.8 \mathrm{~cm}^{-1}$ (in 3A) are shifted to lower absorption bands around $2924 \mathrm{~cm}^{-1}$ (in 2A) due to interaction with silver surface. 4) Stretching vibration of $C=O$ and $C=C$ in $3 \mathrm{~A}$ appeared at 1716.6 and $1666.5 \mathrm{~cm}^{-1}$ respectively, disappeared and new peak appeared at $1743.6 \mathrm{~cm}^{-1}$ in $2 \mathrm{~A}$ probably due to the interaction with the electron Plasmon resonance of silver nano-particles. 5) Four new peaks appeared from $1564-1421.5 \mathrm{~cm}^{-1}$ in $2 \mathrm{~A}$ spectrum. 6) Characteristic bands of anthocyanines appeared from 1118.7 to $1000 \mathrm{~cm}^{-1}$ are disappeared in $2 \mathrm{~A}$ spectrum. All the above mentioned observations confirm a good interaction between anthocyanines molecules and silver nano-particles in their nano-composite sample. This takes place probably due to the binding of natural molecules from $C$ at the surface of the metallic nanoparticles (Fox Junior, 1968). The vibrational frequencies for glicosidic units appear between $1000-1250 \mathrm{~cm}-1$. These bands suggest that the anthocyanins are the organic molecules bounded as ligands at gold/silver nanoparticles (Crisan et al., 2013). Our results agree with Olenic and Chiorean (2015) they studied the interaction of organic molecules with gold/ silver nanoparticles by FTIR spectroscopy and reported that for nanomaterials, the streching vibrations $\mathrm{iOH}$ characteristic to associated $\mathrm{OH}$-groups are shifted to higher values (3396 cm-1 for natural extracts and $3426 / 3435 \mathrm{~cm}^{-1}$ for gold/silver nanomaterials) with about $20 \mathrm{~cm}^{-1}$. This indicates that more $\mathrm{H}$ linkages are broken. $\mathrm{C}=\mathrm{O}$ and $\mathrm{C}=\mathrm{C}$ stretching vibrations in extracts are at $1718 \mathrm{~cm}^{-1}$ and $1594 \mathrm{~cm}^{-1}$. After the reduction of Au3+/Ag+ at Au0/Ag0 with anthocyanins, the peaks are shifted and intensively reduced in intensity $\left(1719 \mathrm{~cm}^{-1}\right.$ and $\left.1629 \mathrm{~cm}^{-1}\right)$.

Morphology of An-AgNPs was studied by SEM tool as shown in Figure 2. The particles are in bundles ranging in size $70-130 \mathrm{~nm}(0.07-0.13 \mu \mathrm{m})$. The size and dimensions of

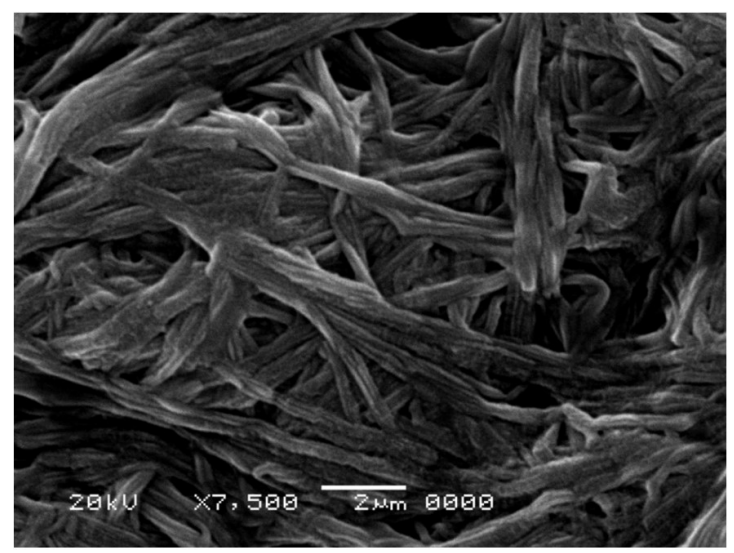

Figure 2. SEM image of prepared An-AgNPs. 
nanoparticles 9-82 $\mathrm{nm}$ for AgNPs-C, and they have an almost spherical or elongated shape (Olenic and Chiorean, 2015).

The results of TC, TG, HDL-C and LDL-C in blood serum are shown in Table 1. Levels of TC, TG and LDL-c blood serum were significantly $(\mathrm{P} \leq 0.05)$ increased in positive control (PC) than normal control (NC), while HDL-c blood serum level was significantly $(\mathrm{P} \leq 0.05)$ decreased (Hendawy et al., 2015). On other hand, administration with An-AgNPs (10, 15, $20 \mathrm{mg} / \mathrm{kg}$ b.w $)+$ MTX significantly $(\mathrm{P} \leq 0.05)$ reversed these results to near NC values. Moreover, An-AgNPs (20 mg/kg b.w) + MTX administrated group gave a result close to NC values. MTX causes many toxicities such as cardiovascular diseases (Baggott et al., 1993). Sabah and Yasmin (2013) studied the effect of MTX on mice and noted that TG and TC serum levels were significantly increase, while HDL serum level was decreased significantly $(\mathrm{P}<0.05)$. Anthocyanin have many bioactivities such as anticardiovascular, antioxidant properties (Hou et al., 2013) and anti-atherosclerotic activity (Xia et al., 2006). Also, Guo et al. (2007) reported that black rice anthocyanin in rich extract has preventing metabolic syndrome property, by improving the lipid profile.

Date presented in Table 2 shows ALT, AST, ALP and LDH activities. The activity of ALT, AST, ALP and LDH blood serum in PC group were significantly $(\mathrm{P} \leq 0.05)$ higher than NC. Although, administration with An-AgNPs at various levels + MTX were significantly $(\mathrm{P} \leq 0.05)$ decreased their activities than those in the PC. An-AgNPs (20 mg/kg b.w) + MTX administrated group gave the best results, which it close with NC values. The increases in the activity of ALT and
AST blood serum levels may be due to MTX cytotoxic effect on liver cells which probably lead to liver cell membrane permeability causing increase the movement of ALT and AST enzymes to the serum of blood (Bonnefoi et al., 1989). Our results agree with Sabah and Yasmin (2013), they showed significant increase in ALP, GOT, and GPT levels in blood serum in mice group administrated by MTX than control group. The levels of ALT activity in MTX treated group was higher significantly $(p=0.001)$ than group of control-saline, this increase demonstrates the hepatotoxicity (Erdogan et al., 2015).

Table 3 shows the results of TBA, SOD and GSH activities. The results showed a significantly $(P \leq 0.05)$, decreased in the activity of SOD and GSH levels in blood serum and significantly ( $\mathrm{p} \leq 0.05)$ increased in the activity of TBA levels in blood serum in treated rats with MTX (20 mg/kg bw) (PC) than NC. However, the groups treated with An$\operatorname{AgNPs}(10,15,20 \mathrm{mg} / \mathrm{kg}$ bw) + MTX reverted TBA, SOD and GSH values to normal levels. GSH levels significant reduction may lead to reduction of effectiveness in the defense system of antioxidant enzyme, which increased, the cell sensitizing to ROS (Babiak et al., 1998). Also, MTX decreasing the antioxidant enzymes levels and causes oxidative liver tissue damage by increasing lipid peroxidation in the tissue of liver (Vardi et al., 2010). Anthocyanin black rice contains tyanidin-3,5-diglucoside; cyanidin-3-, glucoside; cyanidin-3- rutinoside; peonidin-3glucoside and peonidin-3- rutinoside (Zhu et al., 2018), they have many bioactivates such as anti-carcinogenic and antioxidants properties (Hou et al., 2013). Vardi et al. (2010)

Table 1. Effect of An-AgNPs on serum TC, TG, LDL-c and HDL-c concentration in rats treated with methotrexate.

\begin{tabular}{|c|c|c|c|c|}
\hline Treatments & TC mg/dl & TG mg/dl & HDL-C mg/dl & LDL-C mg/dl \\
\hline G1 (NC) & $127.177^{\mathrm{d}} \pm 0.207$ & $65.538^{\mathrm{e}} \pm 0.180$ & $35.612^{\mathrm{b}} \pm 0.238$ & $91.580^{\mathrm{d}} \pm 0.193$ \\
\hline G2 (PC) MTX (20mg/kgb.w) & $304.875^{\mathrm{a}} \pm 0.191$ & $97.715^{\mathrm{a}} \pm 0.140$ & $12.473^{e} \pm 0.181$ & $292.407^{a} \pm 0.310$ \\
\hline G3 (An-AgNPs $10 \mathrm{mg} / \mathrm{kg}$ b.w+MTX) & $185.102^{\mathrm{b}} \pm 0.076$ & $77.152^{\mathrm{b}} \pm 0.057$ & $30.967^{\mathrm{d}} \pm 0.225$ & $154.135^{\mathrm{b}} \pm 0.259$ \\
\hline G4 (An-AgNPs 15 mg/kg b.w+MTX) & $134.980^{`} \pm 0.162$ & $69.177^{c} \pm 0.145$ & $33.512^{c} \pm 0.185$ & $101.468^{c} \pm 0.172$ \\
\hline G5 (An-AgNPs $20 \mathrm{mg} / \mathrm{kg}$ b.w+MTX) & $125.778^{e} \pm 0.120$ & $66.097^{\mathrm{d}} \pm 0.060$ & $37.505^{\mathrm{a}} \pm 0.165$ & $88.333^{\mathrm{e}} \pm 0.244$ \\
\hline LSD & 0.462 & 0.368 & 0.585 & 0.702 \\
\hline
\end{tabular}

$\mathrm{TC}=$ Total cholesterol. TG = Triglycerides. LDL-c $=$ Low density lipoprotein. HDL-c $=$ High density lipoprotein. $\mathrm{NC}=$ Normal control. $\mathrm{PC}=\mathrm{Positive}$ control. MTX = Methotrexate. An-AgNPs = black rice anthocyanins nano-composite. Each value is mean \pm SD for ten rats in each group. Significantly different from controls $(\mathrm{p}<0.05)$ by ANOVA multiple rage test.

Table 2. Effect of An-AgNPs on serum ALT, AST, ALP and LDH concentration in rats treated with methotrexate.

\begin{tabular}{|c|c|c|c|c|}
\hline Treatments & ALT mg/dl & AST mg/dl & $\operatorname{ALP} \mathbf{U} / \mathbf{L}$ & LDH IU/L \\
\hline G1 (NC) & $72.653^{\mathrm{d}} \pm 0.238$ & $173.038^{\mathrm{e}} \pm 0.052$ & $75.507^{b} \pm 0.197$ & $277.968^{\mathrm{d}} \pm 0.051$ \\
\hline G2 (PC) MTX (20mg/kgb.w) & $157.272^{\mathrm{a}} \pm 0.185$ & $268.083^{\mathrm{a}} \pm 0.164$ & $195.997^{e} \pm 0.059$ & $530.088^{a} \pm 0.069$ \\
\hline G3 (An-AgNPs 10 mg/kg b.w+MTX) & $115.028^{\mathrm{b}} \pm 0.065$ & $215.402^{\mathrm{b}} \pm 0.251$ & $126.037^{\mathrm{d}} \pm 0.115$ & $360.403^{b} \pm 0.088$ \\
\hline G4 (An-AgNPs 15 mg/kg b.w+MTX) & $74.248^{c} \pm 0.143$ & $178.145^{`} \pm 0.149$ & $85.998^{c} \pm 0.249$ & $299.907 \_ \pm 0.164$ \\
\hline G5 (An-AgNPs 20 mg/kg b.w+MTX) & $72.980^{\mathrm{e}} \pm 0.047$ & $173.990^{\mathrm{d}} \pm 0.097$ & $76.750^{\mathrm{a}} \pm 0.125$ & $280.242^{\mathrm{e}} \pm 0.125$ \\
\hline LSD & 0.447 & 0.458 & 0.475 & 0.313 \\
\hline
\end{tabular}

$\overline{\mathrm{ALT}}=$ Alanine transferase. AST $=$ Aspartate transferase. $\mathrm{ALP}=$ Alkaline phosphatase $\mathrm{LDH}=$ Lactate dehydrogenase. $\mathrm{NC}=\mathrm{Normal}$ control. $\mathrm{PC}=$ Positive control. MTX = Methotrexate. An-AgNPs = black rice anthocyanins nano-composite. Each value is mean \pm SD for ten rats in each group. Significantly different from controls $(\mathrm{p}<0.05)$ by ANOVA multiple rage test. 
Table 3. Effect of An-AgNPs on serum TBA, SOD and GSH concentration in rats treated with methotrexate.

\begin{tabular}{|c|c|c|c|}
\hline Treatments & TBA nmol/L & SOD U/mL & GSH Mmol/g \\
\hline G1 (NC) & $1.722^{\mathrm{e}} \pm 0.016$ & $110.088^{\mathrm{b}} \pm 0.118$ & $8.202^{\mathrm{b}} \pm 0.025$ \\
\hline G2 (PC) MTX (20mg/kgb.w) & $8.237^{a} \pm 0.039$ & $37.375^{\mathrm{e}} \pm 0.206$ & $3.770^{\mathrm{e}} \pm 0.051$ \\
\hline G3 (An-AgNPs 10 mg/kg b.w+MTX) & $3.790^{\mathrm{b}} \pm 0.026$ & $71.418^{\mathrm{d}} \pm 0.098$ & $6.340^{\mathrm{d}} \pm 0.050$ \\
\hline G4 (An-AgNPs 15 mg/kg b.w+MTX) & $2.098^{c} \pm 0.016$ & $109.163^{c} \pm 0.085$ & $7.870^{\complement} \pm 0.031$ \\
\hline G5 (An-AgNPs 20 mg/kg b.w+MTX) & $1.800^{\mathrm{d}} \pm 0.016$ & $115.022^{\mathrm{a}} \pm 0.039$ & $8.443^{\mathrm{a}} \pm 0.040$ \\
\hline LSD & 0.071 & 0.356 & 0.118 \\
\hline
\end{tabular}

TBA = thiobarbituric acid. SOD = Superoxide dismutase. GSH = Glutathione. NC = Normal control. PC = Positive control. MTX = Methotrexate. An-AgNPs = black rice anthocyanins nano-composite. Each value is mean \pm SD for ten rats in each group. Significantly different from controls $(\mathrm{p}<0.05)$ by ANOVA multiple rage test.

found that the administration of MTX increases MDA level and decreases SOD activity in liver. Saka and Aouacheri (2017) noted a significant reduction in antioxidant enzyme defense system (AEDS) biomarkers of group that intake high-doses MTX, especially the levels of GSH which leads to decrease of AEDS effectiveness, thereby sensitizing the cells to Reactive Oxygen Species (ROS).

\section{Conclusion}

From our results, we can conclude that anthocyanin Nano-composite showed a highly significant protective activity against MTX-included hepatoxicity and reversing the MTX effects on enzymatic and non-enzymatic biomarkers similar to NC, which indicate that anthocyanin Nano-composite is an important mechanism by preventing liver against the side effects of MTX as chemotherapy.

\section{Acknowledgements}

The authors are grateful for the assistance of the Field Crop Technology Research Department, Food Technology Research Institute, Agricultural Research Center, Giza, Egypt.

\section{References}

ALLAIN, C.C., POON, L.S., CHAN, C.S., RICHMOND, W. and FU, P.C., 1974. Enzymatic determination of total serum cholesterol. Clinical Chemistry, vol. 20, no. 4, pp. 470-475. http://dx.doi. org/10.1093/clinchem/20.4.470. PMid:4818200.

AMIN, F.U., SHAH, S.A., BADSHAH, H., KHAN, M. and KIM, M.O., 2017. Anthocyanins encapsulated by PLGA@ PEG nanoparticles potentially improved its free radical scavenging capabilities via p38/JNK pathway against A $\beta$ 1-42-induced oxidative stress. Journal of Nanobiotechnology, vol. 15, no. 1, pp. 12. http://dx.doi. org/10.1186/s12951-016-0227-4. PMid:28173812.

BABIAK, R.M.V., CAMPELLO, A.P., CARNIERI, E.G.S. and OLIVEIRA, M.B.M., 1998. Methotrexate: pentose cycle and oxidative stress. Cell Biochemistry and Function, vol. 16, no. 4, pp. 283-293. http:// dx.doi.org/10.1002/(SICI)1099-0844(1998120)16:4<283::AIDCBF801>3.0.CO;2-E. PMid:9857491.

BABLOK, W., PASSING, H., BENDER, R. and SCHNEIDER, B.A., 1988. General regression procedure for method transformation. application of linear regression procedures for method comparison studies in clinical chemistry, part III. Clinical Chemistry and Laboratory Medicine, vol. 26, no. 11, pp. 783-790. http://dx.doi.org/10.1515/cclm.1988.26.11.783. PMid:3235954.

BAGGOTT, J.E., MORGAN, S.L., HA, T.S., ALARCON, G.S., KOOPMAN, W.J. and KRUMDIECK, C.L., 1993. Antifolates in rheumatoid arthritis: a hypothetical mechanism of action. Clinical and Experimental Rheumatology, vol. 11, suppl. 8, pp. S101-S105. PMid:8324932.

BARNES, C.A., ELSAESSER, A., ARKUSZ, J., SMOK, A., PALUS, J., LEŚNIAK, A., SALVATI, A., HANRAHAN, J.P., JONG, W.H., DZIUBAŁTOWSKA, E., STEPPIK, M., RYDZYŃSKI, K., MCKERR, G., LYNCH, I., DAWSON, K.A. and HOWARD, C.V., 2008. Reproducible comet assay of amorphous silica nanoparticles detects no genotoxicity. Nano Letters, vol. 8, no. 9, pp. 3069-3074. http:// dx.doi.org/10.1021/nl801661w. PMid:18698730.

BONNEFOI, M., HASIM, M., SAUVAGNAC, P., BURGAT, V. and BRAUN, J.P., 1989. Liver enzyme changes in a guinea-pig model of facial eczema (sporidesmiotoxicosis). Enzyme, vol. 42, no. 1, pp. 39-46. http://dx.doi.org/10.1159/000469005. PMid:2570691.

BOWEN-FORBES, C.S., ZHANG, Y. and NAIR, M.G., 2010. Anthocyanin content, antioxidant, anti-inflammatory and anticancer properties of blackberry and raspberry fruits. Journal of Food Composition and Analysis, vol. 23, no. 6, pp. 554-560. http:// dx.doi.org/10.1016/j.jfca.2009.08.012.

CELIK, F., GOCMEZ, C., BOZKURT, M., KAPLAN, I., KAMASAK, K., AKIL, E., DOGAN, E., GUZEL, A. and UZAR, E., 2013. Neuroprotective effects of carvacrol and pomegranate against methotrexate induced toxicity in rats. European Review for Medical and Pharmacological Sciences, vol. 17, no. 22, pp. 2988-2993. PMid:24302176.

CRISAN, M., DAVID, L., MOLDOVAN, B., VULCU, A., DREVE, S., PERDESCHREPLER, M., TATOMIR, C., FILIP, A.G., BOLFA, P., ACHIM, M., CHIOREAN, I., KACSO, I., GROSAN, C.B. and OLENIC, L., 2013. New nanomaterials for the improvement of psoriatic lesions. Journal of Materials Chemistry. B, Materials for Biology and Medicine, vol. 1, no. 25, pp. 3152-3158. http://dx.doi.org/10.1039/c3tb20476f. PMid:32260915.

DAVID, L., MOLDOVAN, B., VULCU, A., OLENIC, L., PERDESCHREPLER, M., FISCHER-FODOR, E., FLOREA, A., CRISAN, M., CHIOREAN, I., CLICHICI, S. and FILIP, G.A., 2014. Green synthesis, characterization and anti-inflammatory activity of silver nanoparticles using european black elderberry fruits extract. Colloids and Surfaces. B, Biointerfaces, vol. 122, pp. 767-777. http://dx.doi.org/10.1016/j.colsurfb.2014.08.018. PMid:25174985.

ELLMAN, G.L., 1959. Tissue sulfhydryl groups. Archives of Biochemistry and Biophysics, vol. 82, no. 1, pp. 70-77. http:// dx.doi.org/10.1016/0003-9861(59)90090-6. PMid:13650640. 
ERDOGAN, E., ILGAZ, Y., GURGOR, P.N., OZTAS, Y., TOPAL, T. and OZTAS, E., 2015. Rutin ameliorates methotrexate induced hepatic injury in rats. Acta Cirurgica Brasileira, vol. 30, no. 11, pp. 778784. http://dx.doi.org/10.1590/S0102-865020150110000009. PMid:26647798.

FOSSATI, P. and PRENCIPE, L., 1982. Serum triglycerides determined colorimetrically with an enzyme that produces hydrogen peroxide. Clinical Chemistry, vol. 28, no. 10, pp. 2077-2080. http://dx.doi.org/10.1093/clinchem/28.10.2077. PMid:6812986.

FOX JUNIOR, C.L., 1968. Silver sulfadiazine: a new topical therapy for Pseudomonas in burns. Archives of Surgery, vol. 96, no. 2, pp. 184188. http://dx.doi.org/10.1001/archsurg.1968.01330200022004. PMid:5638080.

FRIEDEWALD, W.T., LEVY, R.I. and FREDRICKSON, D.S., 1972. Estimation of the concentration of low-density lipoprotein cholesterol in plasma, without use of the preparative ultracentrifuge. Clinical Chemistry, vol. 18, pp. 499-502. http:// dx.doi.org/10.1093/clinchem/18.6.499. PMid:4337382.

GUO, H., LING, W., WANG, Q., LIU, C., HU, Y., XIA, M., FENG, X. and XIA, X., 2007. Effect of anthocyanin-rich extract from black rice (Oryza sativa L. indica) on hyperlipidemia and insulin resistance in fructose-fed rats. Plant Foods for Human Nutrition, vol. 62 , no. 1, pp. 1-6. http://dx.doi.org/10.1007/s11130-006-0031-7. PMid:17187297.

HENDAWY, O.M., AHMED, W.M.S., ABOSAIF, A.A. and MAHMOUD, F.A., 2015. Effect of atorvastatin and vitamin D on Freund's adjuvant-induced rheumatoid arthritis in rat. Journal of Bioequivalence \& Bioavailability, vol. 7, pp. 90-94.

HOU, F., ZHANG, R., ZHANG, M., SU, D., WEI, Z., DENG, Y., ZHANG, Y., CHI, J. and TANG, X., 2013. Hepatoprotective and antioxidant activity of anthocyanins in black rice bran on carbon tetrachloride-induced liver injury in mice. Journal of Functional Foods, vol. 5, no. 4, pp. 1705-1713. http://dx.doi. org/10.1016/j.jff.2013.07.015.

KONG, J.M., CHIA, L.S., GOH, N.K., CHIA, T.F. and BROUILLARD, R., 2003. Analysis and biological activities of anthocyanins. Phytochemistry, vol. 64, no. 5, pp. 923-933. http://dx.doi. org/10.1016/S0031-9422(03)00438-2. PMid:14561507.

KUMARI, S., 2016. Methotrexate induced hepatotoxicity and its management. International Journal of Science and Research, vol. 5, pp. 1477-1481.

LOPEZ-VIRELLA, M., STONE, S., ELLIS, S. and COLWELL, J.A., 1977. Cholesterol determination in high density lipoproteins separated by three different methods. Clinical Chemistry, vol. 23, no. 5 , pp. 882-884. http://dx.doi.org/10.1093/clinchem/23.5.882. PMid:192488.

MIHARA, M. and UCHIYAMA, M., 1978. Determination of malonaldehyde precursor in tissues by thiobarbituric acid test. Analytical Biochemistry, vol. 86, no. 1, pp. 271-278. http://dx.doi. org/10.1016/0003-2697(78)90342-1. PMid:655387.

MIYAKE, S., TAKAHASHI, N., SASAKI, M., KOBAYASHI, S., TSUBOTA, K. and OZAWA, Y., 2012. Vision preservation during retinal inflammation by anthocyanin-rich bilberry extract: cellular and molecular mechanism. Laboratory Investigation, vol. 92, no. 1, pp. 102-109. http://dx.doi.org/10.1038/labinvest.2011.132. PMid:21894150.

OHKUMA, N., MATSUO, S., TUTSUI, M. and OHKAWARA, A., 1982. Superoxide dismutase in the epidermis. The Japanese Journal of Dermatology, vol. 92, pp. 583-590.

OLENIC, L. and CHIOREAN, I., 2015. Synthesis, characterization and application of nanomaterials based on noble metallic nanoparticles and anthocyanins. International Journal of Latest Research in Science and Technology, vol. 4, no. 2, pp. 6-22.
OZOGUL, B., KISAOGLU, A., TURAN, M.I., ALTUNER, D., SENER, E., CETIN, N. and OZTURK, C., 2013. The effect of mirtazapine on methotrexate-induced toxicity in rat liver. Sci Asia, vol. 39, no. 4, pp. 356-362. http://dx.doi.org/10.2306/ scienceasia1513-1874.2013.39.356.

RAI, M., YADAV, A. and GADE, A., 2009. Silver nanoparticles as a new generation of antimicrobials. Biotechnology Advances, vol. 27, no. 1, pp. 76-83. http://dx.doi.org/10.1016/j.biotechadv.2008.09.002. PMid:18854209.

REITMAN, S. and FRANKEL, S.A., 1957. Colorimetric method for the determination of serum glutamic oxaloacetic and glutamic pyruvic transaminases. American Journal of Clinical Pathology, vol. 28, no. 1, pp. 56-63. http://dx.doi.org/10.1093/ajcp/28.1.56. PMid:13458125.

SABAH, N.A. and YASMIN, L.A., 2013. Effect of methotrexate on the liver enzymes and lipid profile in adult female albino mice. Baghdad Science Journal, vol. 10, no. 1, pp. 176-181. http://dx.doi. org/10.21123/bsj.10.1.176-181.

SAKA, S. and AOUACHERI, O., 2017. The Investigation of the oxidative stress-related parameters in high doses methotrexate-induced albino wistar rats. Journal of Bioequivalence \& Bioavailability, vol. 9, pp. 372-376.

SANKHARI, J.M., THOUNAOJAM, M.C., JADEJA, R.N., DEVKAR, R.V. and RAMACHANDRAN, A., 2012. Anthocyanin-rich red cabbage (Brassica oleracea L.) extract attenuates cardiac and hepatic oxidative stress in rats fed an atherogenic diet. Journal of the Science of Food and Agriculture, vol. 92, no. 8, pp. 1688-1693. http://dx.doi.org/10.1002/jsfa.5532. PMid:22228433.

ŞENER, G., EKSIOGLU-DEMIRALP, E., CETINER, M., ERCAN, F. and YEGEN, B.C., 2006b. Betaglucan ameliorates methotrexateinduced oxidative organ injury via its antioxidant and immunomodulatory effects. European Journal of Pharmacology, vol. 542, no. 1-3, pp. 170-178. http://dx.doi.org/10.1016/j. ejphar.2006.02.056. PMid:16793036.

ŞENER, G., EKŞIOĞLU-DEMIRALP, E., CETINER, M., ERCAN, F., SIRVANCI, S., GEDIK, N. and YEĞEN, B.C., 2006a. L-carnitine ameliorates methotrexate-induced oxidative organ injury and inhibits leukocyte death. Cell Biology and Toxicology, vol. 22, no. 1, pp. 47-60. http://dx.doi.org/10.1007/s10565-006-0025-0. PMid:16463019.

SEPTIANI, N.L.W., YULIARTO, B., IQBAL, M. and NUGRAHA., 2017. Synthesis of zinc oxide nanoparticles using anthocyanin as a capping agent. IOP Conference Series. Materials Science and Engineering, vol. 202, pp. 012070. http://dx.doi.org/10.1088/1757899X/202/1/012070.

TAVARES, P., BALBINOT, F., OLIVEIRA, H.M., FAGUNDES, G.E., VENÂNCIO, M., RONCONI, J.V., MERLINI, A., STRECK, E.L., SILVA PAULA, M.M. and ANDRADE, V.M., 2012. Evaluation of genotoxic effect of silver nanoparticles (Ag-Nps) in vitro and in vivo. Journal of Nanoparticle Research, vol. 14, no. 4, pp. 791. http:// dx.doi.org/10.1007/s11051-012-0791-y.

THOMAS, K. and SAYRE, P., 2005. Research strategies for safety evaluation of nanomaterials, part I: evaluating the human health implications of exposure to nanoscale materials. Toxicological Sciences, vol. 87, no. 2, pp. 316-321. http://dx.doi.org/10.1093/ toxsci/kfi270. PMid:16049265.

VARDI, N., PARLAKPINAR, H., CETIN, A., ERDOGAN, A. and CETIN OZTURK, I., 2010. Protective effect of $\beta$-carotene on methotrexateinduced oxidative liver damage. Toxicologic Pathology, vol. 38, no. 4, pp. 592-597. http://dx.doi.org/10.1177/0192623310367806. PMid:20448084.

XIA, X., LING, W., MA, J., XIA, M., HOU, M., WANG, Q., ZHU, H. and TANG, Z., 2006. An anthocyanin-rich extract from 
black rice enhances atherosclerotic plaque stabilization in apolipoprotein e-deficient mice. The Journal of Nutrition, vol. 136, no. 8, pp. 2220-2225. http://dx.doi.org/10.1093/ jn/136.8.2220. PMid:16857844.
ZHU, Y., SUN, H., HE, S., LOU, Q., YU, M., TANG, M. and TU, L., 2018. Metabolism and prebiotics activity of anthocyanins from black rice (Oryza sativa L.) in vitro. PLoS One, vol. 13, no. 4, e0195754. http://dx.doi.org/10.1371/journal.pone.0195754. PMid:29630662. 